\title{
Gluconic Acid
}

National Cancer Institute

\section{Source}

National Cancer Institute. Gluconic Acid. NCI Thesaurus. Code C61777.

The carboxylic acid formed by the oxidation of the first carbon of glucose with antiseptic and chelating properties. Gluconic acid, found abundantly in plant, honey and wine, can be prepared by fung al fermentation process commercially. This agent and its derivatives can used in formulation of pharmaceuticals, cosmetics and food products as additive or buffer salts. Aqueous gluconic acid solution contains cyclic ester glucono delta lactone structure, which chelates metal ions and forms very stable complexes. In alkaline solution, this agent exhibits strong chelating activities towards anions, i.e. calcium, iron, aluminium, copper, and other heavy metals. 